\title{
Analisa Sebaran Banjir Akibat Keruntuhan Waduk Wadaslintang
}

\author{
Roni Dwi Kurniyawan ${ }^{\mathrm{a}^{*}}$, Ratna Septi Hendrasari ${ }^{\mathrm{a}}$ \\ Jurusan Teknik Sipil, Fakultas Sains dan Teknologi, Universitas Teknologi Yogyakarta, Indonesia
}

Keywords:

Debit Inflow

Flood

DAM Break

\begin{abstract}
A heavy rain that happened in upstream area caused the increasing of debit inflow into the reservoir. If debit inflow got into the reservoir was big, so that, it caused the water overflowing from the top of reservoir. Thus, it caused the reservoir collapse that made a flood. The objective of this research was to know the map of flood spread when the reservoir was collapse and to know the flood speed and time towards the downstream. The method used is unit hirograf in having the calculation by HSS Nakayasu and the next was taken model by software HEC-RAS 5.06. From the result obtained the conclusion that breaking reservoir in $Q_{P M F}$. The result of flood hirograf data in dam break location using HEC-RAS application in HEC-RAS was the deepest flood in $8,1 \mathrm{~m}$ with the fastest maximum speed in $8,17 \mathrm{~m} / \mathrm{s}$, and the time needed by the flood to DAS Wawar, downstream area was for 0,78 hour.
\end{abstract}

\begin{abstract}
ABSTRAK
Hujan yang terjadi pada daerah hulu dengan intensitas tinggi akan mengakibatkan peningkatan debit inflow yang masuk ke waduk. Apabila debit inflow yang masuk ke waduk besar maka dapat mengakibatkan meluapnya air melalui puncak bendungan. Hal ini dapat mengakibatkan terjadinya keruntuhan bendungan yang dapat menimbulkan bencana banjir. Tujuan penelitian ini adalah untuk mengetahui peta sebaran banjir saat bendungan runtuh dan mengetahui kecepatan dan waktu banjir tersebut mencapai ke daerah hilir. Metode yang digunakan adalah hirograf satuan dihitung dengan HSS Nakayasu dan selanjutnya dimodelkan menggunakan software HEC-RAS 5.06. Dari hasil penelitian diperoleh kesimpulan bahwa bendungan breaking pada saat QPMF. Hasil data hidrograf banjir pada lokasi dam break dengan aplikasi HEC-RAS pada saat QPMF adalah kedalaman banjir tertinggi sebesar 8,1 m dengan kecepatan maksimum tertinggi sebesar $8,17 \mathrm{~m} / \mathrm{dt}$., serta waktu yang dibutuhkan banjir untuk sampai ke daerah hilir DAS Wawar adalah selama 0,78 jam.
\end{abstract}

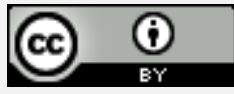

This is an open access article under the CC-BY license.

\section{Pendahuluan}

Waduk merupakan danau alam atau buatan atau tempat penyimpanan air dengan cara membendung sungai untuk penyediaan berbagi keperluan antara lain irigasi pertanian, pembangkit tenaga listrik, dan juga untuk obyek wisata. Waduk multi guna adalah waduk yang dioperasikan untuk memenuhi berbagai macam kebutuhan, misalnya untuk kebutuhan air irigasi maupun air baku dan sebagainya.

Waduk Wadaslintang adalah sebuah waduk multi guna (multy purpose dam) yang memiliki fungsi sebagai penyedia air bagi kebutuhan irigasi, penghasil tenaga listrik (PLTA), serta pengatur debit air untuk mencegah banjir. Waduk Wadaslintang terletak di wilayah kecamatan Wadaslintang, Kabupaten Wonosobo, Jawa
Tengah atau lebih tepatnya di bagian selatan wilayah Kecamatan Wadaslintang yang berbatasan langsung dengan Kecamatan Padureso di Kabupaten Kebumen. Waduk ini menggunakan Kali Gede sebagai sumber air utamanya dengan menggunakan anak sungai kecil lainnya yang menyuplai air ke Waduk Wadaslintang. Sungai tersebut antara lain Sungai Lancar, Sungai Waturangkang, Sungai Somagede dan Sungai Tritis, Luas Daerah Tangkapan Air (DTA) waduk ini mencapai 229,49 km2. [1]. Peta lokasi waduk dapat dilihat pada Gambar 1.

Kondisi cuaca sangat tidak menentu dan sering terjadi hujan dengan intensitas tinggi selama berhari-hari pada daerah hulu yang mengakibatkan meningkatnya debit inflow yang masuk ke waduk. Apabila debit inflow yang masuk ke waduk besar dapat meluapnya air melalui puncak bendungan atau biasa disebut dengan overtopping. 
Kondisi ini dapat mengakibatkan terjadinya keruntuhan pada bendungan (dam breaking). Dam breaking mampu menimbulkan bencana banjir besar pada daerah hilir. Bencana yang ditimbulkan tidak hanya terjadi pada sekitar bendungan namun akan menyebar sampai jauh ke daerah hilir yang mencakup area yang luas. Hal ini akan menimbukan dampak yang cukup besar antara lain tergenangnya beberapa daerah pada daerah hilir bendugan, sehingga mengakibatkan rusaknya lahan pertanian, pemukiman, serta sarana transpotasi. Berkaitan dengan hal ini maka perlu dilakukan penelitian mengenai sebaran banjir jika bendungan mengalami keruntuhan. Dengan mengetahui sebaran banjir yang terjadi, maka penyiapan mitigasi bencana dapat dimaksimalkan.

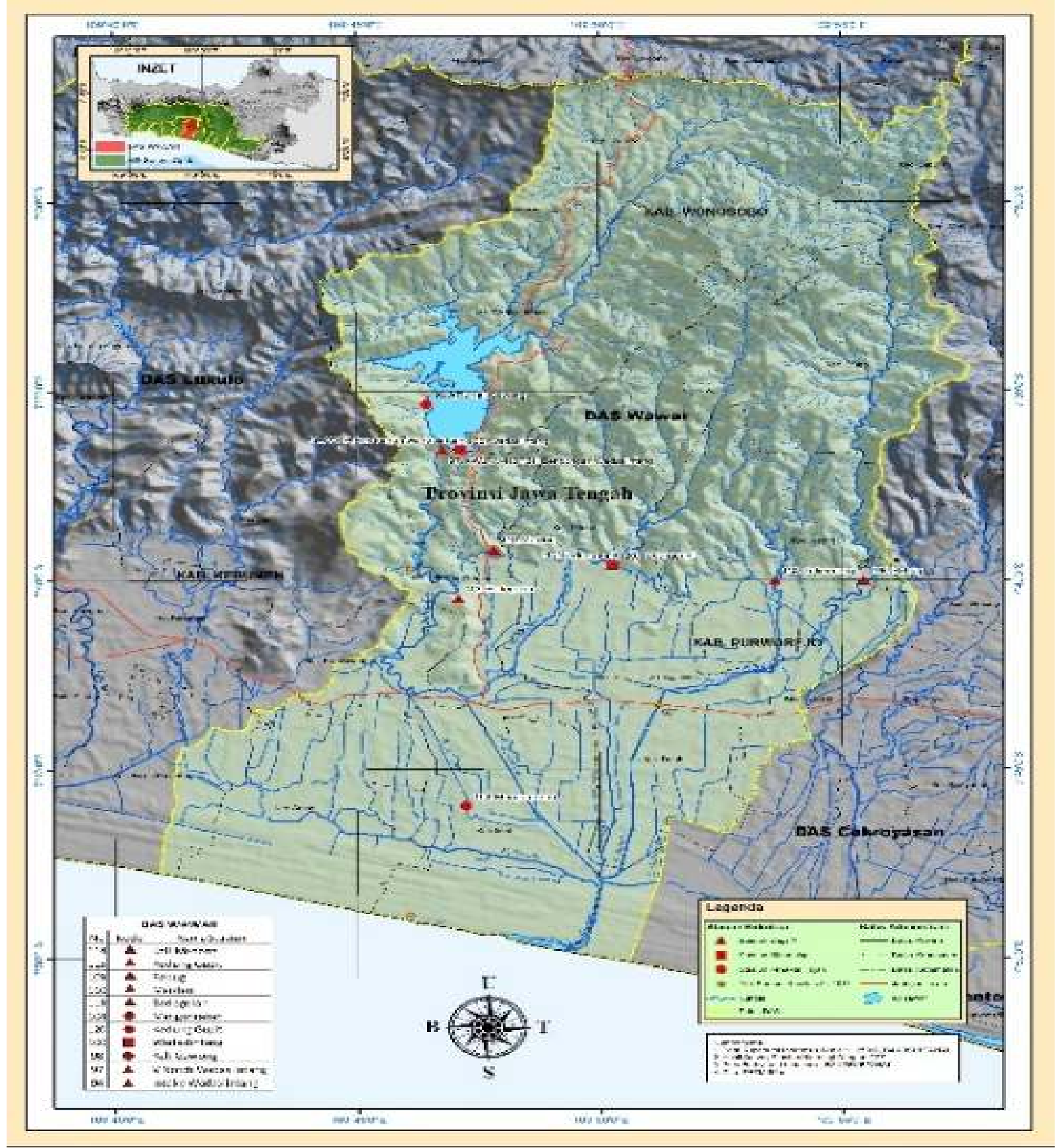

Gambar 1. Peta Lokasi Waduk Wadaslintang [1] 


\section{Metode}

Penelitian ini merupakan penelitian yang meliputi tahapan-tahapan mulai dari mencari data, mengolah data, hingga mendapatkan hasil data yang diharapkan. Analisis yang dilakukan dalam penelitian ini adalah analisis hidrologi. Analisis hidrologi digunakan untuk mendapatkan hujan rencana dengan kala ulang 2, 5, 10, 25, 50, 100, dan 200 tahunan. Pada analisis ini data yang digunakan berdasarkan data sekunder yaitu data curah hujan. Data ini didapatkan dari Balai PSDA Progo Bogowonto Luk Ulo pada tahun 2016 dengan kurun waktu tiga tahun yakni tahun 2010 sampai dengan 2012 dari pos hujan Kaliwiro, Sumberejo, dan Limbangan [2].

\subsection{Uji Konsistensi data}

Uji ini dilakukan dengan metode Kurva Massa Ganda. Uji ini ditujukan untuk mengetahui kecocokan data curah hujan yang akan digunakan dalam penelitian selanjutnya.

\subsection{Curah Hujan Rerata Kawasan}

Dalam analisis hidrologi sering digunakan Metode Rerata Aljabar, Metode Poligon Thiesen dan Metode Isohiet. Dalam penelitian ini penulis menggunakan Metode Polygon Thiessen dengan menggunakan tiga stasiun hujan. Perhitungan Polygon Thiessen dapat dilihat pada Persamaan 1.

$$
\begin{aligned}
& P \\
& =\frac{A_{1} p_{1}+A_{2} p_{2}+\ldots+A_{n} p_{n}}{A_{1}+A_{2}+\ldots+A_{n}}
\end{aligned}
$$

Dimana $P$ adalah hujan rerata kawasan $(\mathrm{mm}), \mathrm{P}_{1}$ dan $\mathrm{P}_{\mathrm{n}}$ adalah hujan pada stasiun $1, \mathrm{n}(\mathrm{mm}), \mathrm{A}_{1}, \mathrm{~A}_{2}, ., \mathrm{A}_{\mathrm{n}}$ merupakan luas daerah yang mewakili stasiun $1,2, \ldots, n$ $\left(\mathrm{km}^{2}\right)[3]$.

\subsection{Analisis frekuensi}

Tujuan analisis frekuensi data hidrologi adalah berkaitan dengan besaran peristiwa-peristiwa ekstrim yang berkaitan dengan frekuensi kejadiannya melalui penerapan distribusi kemungkinan. Data hidrologi yang dianalisis diasumsikan tidak bergantung (independent) dan terdistribusi secara acak dan bersifat stokastik. [4].

Dalam ilmu statistik dikenal beberapa macam distribusi frekuensi dan yang paling digunakan adalah Distribusi Normal, Distribusi Log Normal, Distribusi Log Pearson Tipe III, dan Distribusi Gumbel. Adapun untuk menentukan metode yang akan digunakan dapat dihitung dengan menggunakan beberapa parameter yaitu rerata $(\mathrm{X})$, standar deviasi $(S)$, koefisien variansi $(\mathrm{Cv})$, koefisien skewness (Cs), dan koefisien kurtosis (Ck). Tabel parameter statistik dapat dilihat pada Tabel 1.

\subsection{Pemilihan Jenis Distribusi}

Pemilihan jenis distribusi dilakukan dengan melakukan perbandingan antar koefisien distribusi dari metode yang akan digunakan. Masing-masing distribusi mempunyai syarat seperti yang tertera pada Tabel 2 .

\subsection{Kecocokan Jenis Distribusi}

Pengujian parameter statistik untuk menentukan kecocokan jenis distribusi frekuensi dari sampel data terhadap fungi distribusi peluang yang diperkirakan dapat mewakili distribusi frekuensi. Uji kecocokan jenis distribusi menggunakan dua yaitu: Metode Chi-Kuadrat dan Smirnov Komogorov.

\subsection{Curah Hujan Rencana}

Analisa curah hujan rencana adalah untuk mengetahui besarnya curah hujan harian maksimum dalam suatu periode ulang yang digunakan untuk menghitung debit banjir rencana. Perhitungan curah hujan rencana dapat dilihat pada Persamaan 2 [3].

$$
X t=\operatorname{Tr}+(K x S)
$$

Dengan Tr adalah nilai curah hujan rerata maksimum $(\mathrm{mm}), \mathrm{S}$ adalah nilai standar deviasi, $\mathrm{K}$ adalah faktor frekuensi yang nilainya berdasarkan nilai Cs (koefisien kemencengan).

\subsection{Hujan Rancangan Metode ABM}

Hyetograph hujan rencana yang dihasilkan oleh metode Alternating Block Method (ABM) adalah hujan yang terjadi dalam $\mathrm{n}$ rangkaian interval waktu yang berurutan dengan durasi $\Delta \mathrm{t}$ selama waktu tertentu. Hyetograph merupakan hujan rancangan yang didistribusikan ke dalam kedalaman hujan jam-jaman. Intensitas hujan dihitung dengan persamaan 3, hujan jam-jaman dihitung dengan persamaan 4, dan perhitungan hyetograph menggunakan persamaan 5 [3].

$I_{t}=I_{t}=\frac{X_{T}}{24}\left(\frac{24}{T_{d}}\right)^{\frac{2}{3}}$

$\mathrm{Pt}=\frac{\Delta \mathrm{p} 1}{\Delta \mathrm{ptot}} \times 100$

Hyetograph $=\frac{\text { hyetograph }(\%)}{\mathrm{xt}} \times 100$

It adalah hujan rancangan $(\mathrm{mm}), \mathrm{X}_{\mathrm{T}}$ adalah hujan rencana kala ulang tertentu (mm), $\mathrm{T}_{\mathrm{d}}$ lamanya hujan dalam lokasi (jam). $\Delta p$ adalah selisih kedalaman hujan (mm). 
Tabel 1. Parameter Statistik [5]

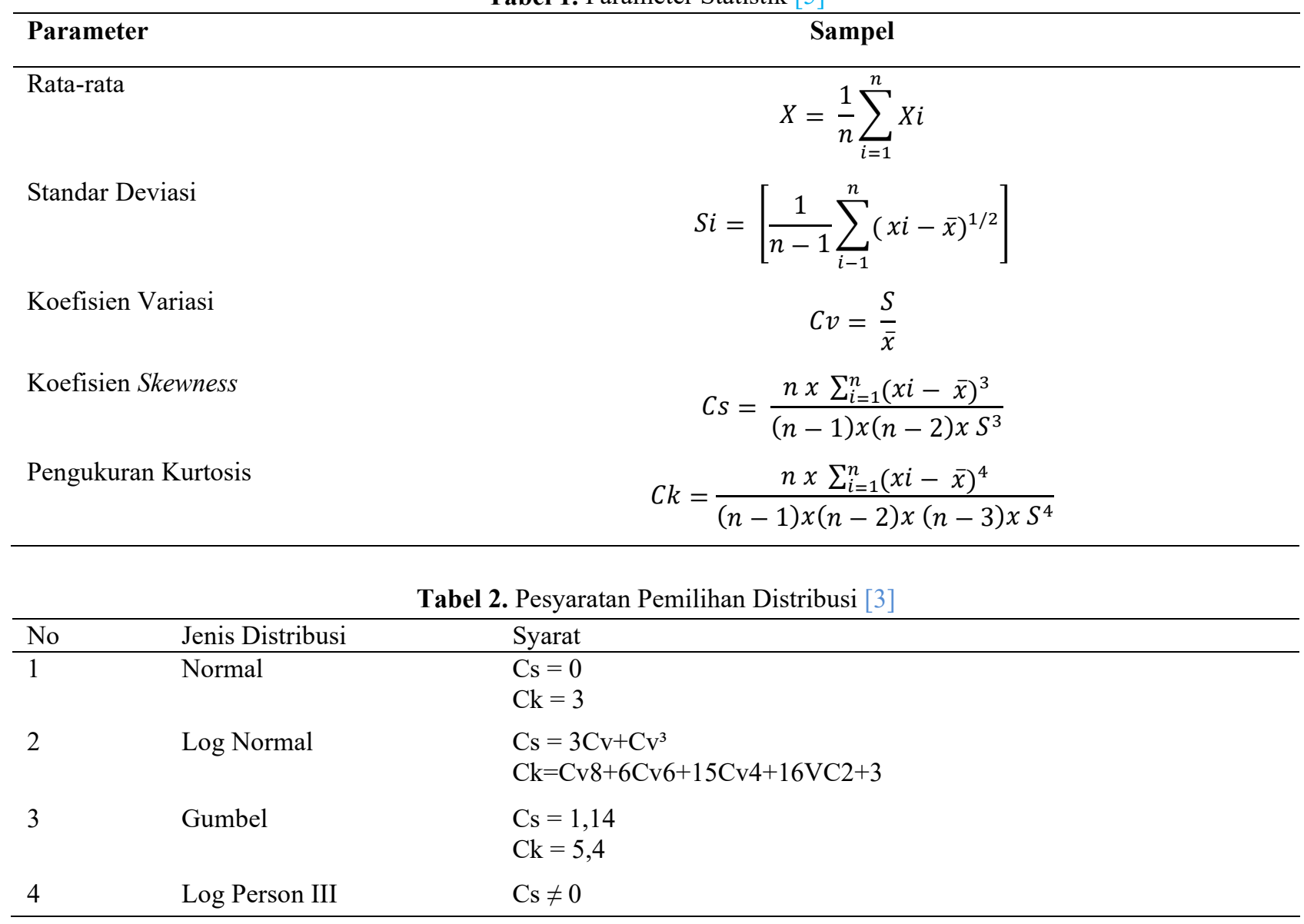

\subsection{Debit Banjir Rancangan}

Di daerah di mana data hidrologi tidak tersedia untuk menurunkan hidrograf satuan, maka dibuat hidrograf satuan sintetis yang didasarkan pada karakteristik fisik dari DAS. Dalam hal ini perhitungan dilakukan dengan menggunakan metode Hidrograf Satuan Sintetis (HSS) Nakayasu. Hidrograf Satuan Sintetik Nakayasu dikembangkan berdasarkan beberapa sungai di Jepang [5]. Bentuk HSS Nakayasu sesuai seperti Gambar 2.

$$
\begin{aligned}
& Q_{p}=\frac{1}{3,6}\left(\frac{A R e}{0,3 T_{p}+T_{0,3}}\right) \\
& T_{p}=t_{g}+0,8 T_{r} \\
& t_{g}=0,4+0,0058 L \\
& \text { untuk } \mathrm{L}>15 \mathrm{~km} \\
& t_{g}=0,21 L^{0,7} \\
& \text { untuk } \mathrm{L}<15 \mathrm{~km}
\end{aligned}
$$

$$
\begin{aligned}
& T_{0,3}=\alpha t_{g} \\
& T_{r}=0,5 t_{g} \text { sampai } t_{g}
\end{aligned}
$$

Dimana $\mathrm{Q}_{\mathrm{p}}$ adalah debit puncak banjir $\left(\mathrm{m}^{3} / \mathrm{dt}\right), A$ adalah luas DAS $\left(\mathrm{km}^{2}\right)$, Re adalah curah hujan (mm), $T_{p}$ adalah waktu dari permulaan banjir sampai ke puncak hidrograf (jam), $T_{0,3}$ adalah waktu dari puncak banjir sampai ke 0,3 kali debit puncak (jam), $t_{g}$ adalah waktu konsentrasi (jam), $T_{r}$ adalah satuan waktu dari curah hujan (jam), $\alpha$ adalah koefisien karakteristik DAS, biasanya diambil 2, $L$ adalah panjang sungai utama $(\mathrm{km})$.

\subsection{Analisis Dam Break dengan HEC-RAS}

HEC-RAS merupakan program aplikasi untuk memodelkan aliran satu dimensi dan dua dimensi di sungai atau saluran, River Analysis System (RAS), dibuat oleh Hydrologic Engineering Center (HEC) yang merupakan satu divisi di dalam Institute for Water Resources (IWR), di bawah US Army Corps of Engineers (USACE) [6], [7]. 


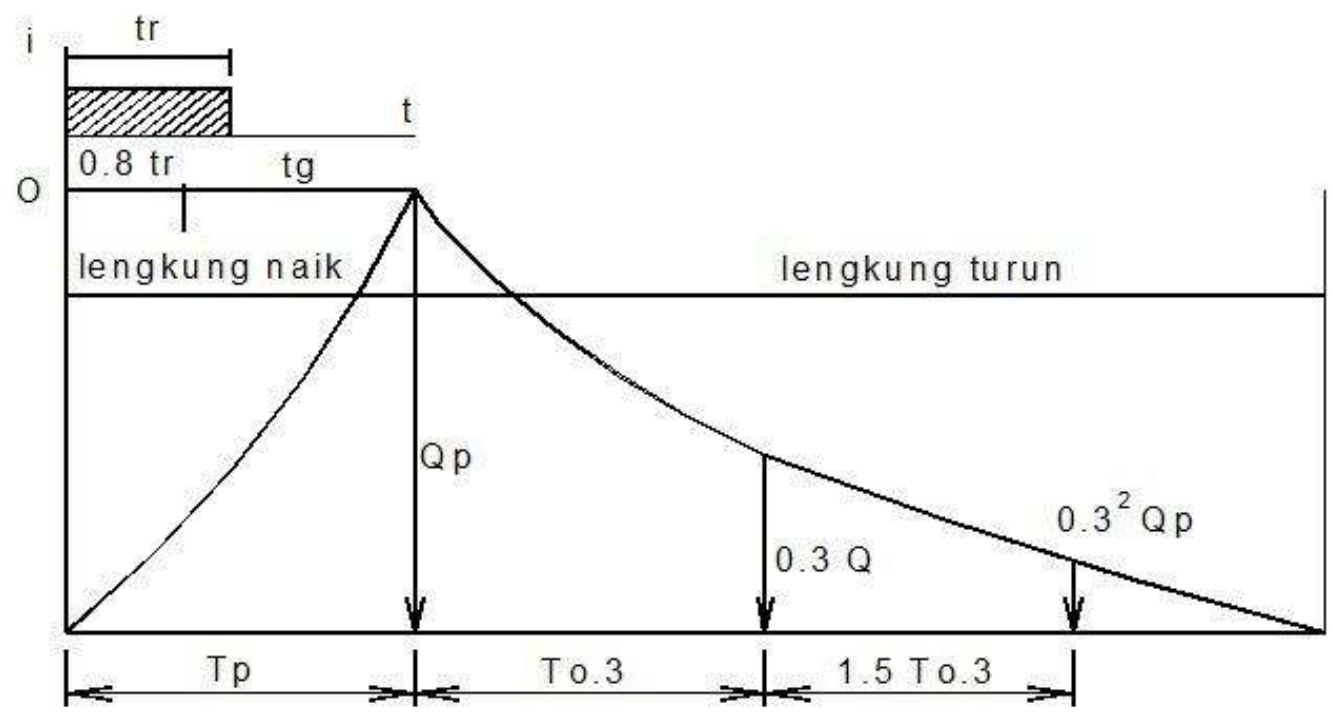

Gambar 2. Hidrograf Satuan Sintetik Nakayasu

Terdapat lima langkah penting dalam membuat model hidrolika dengan menggunakan HEC-RAS:

1. Memulai projek baru

2. Memasukkan data geometri

3. Memasukkan data aliran dan kondisi batas

4. Melakukan perhitungan hidrolika

5. Menampilkan dan mencetak hasil.

\section{Hasil Dan Pembahasan}

\subsection{Analisis Hidrologi}

Dalam analisis data hujan dilakukan uji konsistensi data hujan. Pengujian ini bertujuan untuk mengetahui apakah data curah hujan yang diperoleh sudah konsisten atau belum. Uji ini menggunakan metode Kurva Massa Ganda dari tiga stasiun hujan, yaitu: Sumberejo, Kaliwiro, dan Limbangan yang terdiri dari tahun 2010 hingga tahun 2012. Berdasarkan hasil pengujian didapatkan bahwa data konsisten karena tidak terjadi patahan pada uji ini.

Metode perhitungan curah hujan kawasan pada Waduk Wadaslintang menggunakan metode Poligon Thiessen yang diperoleh dengan menggunakan software ARCGIS dengan faktor pembobot untuk masing - masing stasiun hujan. Karena hanya terdapat tiga tahun hujan pada ketiga stasiun hujan maka dilakukan analisis dengan metode partial series yaitu dengan menentukan batas bawah untuk menentukan curah hujan baru yang berada di atas batas bawah. Penulis menentukan batas bawah sebesar 65 sehingga diperoleh 12 data yang berada di atas nilai 65 . Hasil perhitungan curah hujan maksimum dapat dilihat pada Tabel 3.
Parameter statistik frekuensi hujan diperlukan untuk menentukan jenis distribusi. Hasil perhitungan parameter statistik hujan dapat dilihat pada Tabel 4. Berdasarkan Tabel 4 didapatkan bahwa yang memenuhi persyaratan distribusi adalah metode Log Pearson III.

Pengujian menentukan apakah persamaan distribusi peluang yang telah dipilih dapat mewakvili distribusi statistik sampel data (Soewarno, 1995). Pengujian parameter dilakukan dengan dua cara, yaitu uji ChiKuadrat dan uji Smirnov-Kolmogorov. Hasil perhitungan uji Chi-Kuadrat dapat dilihat pada Tabel 5.

Dari perhitungan Chi Kuadrat didapat nilai $\mathrm{X}^{2}=4,667<$ $\mathrm{X}_{\mathrm{kr}}^{2}=5,991$. Berdasarkan tabel nilai kritis untuk uji keselarasan chi-kuadrat dimana dengan nilai $\alpha=5 \%$, dan $\mathrm{X}^{2}$ tidak boleh lebih dari 5,991. Sehingga agihan $\log$ Pearson III dengan derajat kepercayaan 95\% dapat diterima.

Dari perhitungan nilai $\mathrm{D}$, menunjukan nilai $\mathrm{D}_{\max }=$ 0,16783, data pada peringkat $\mathrm{m}=12$. Dengan menggunakan data pada tabel $D_{\text {kritik }}$ untuk derajat kepercayaan $5 \%$, maka diperoleh $\mathrm{D} \alpha=0,3$. Karena nilai $\mathrm{D}_{\max }$ lebih kecil dari nilai $\mathrm{D} \alpha(0.16783<0,3)$, maka persamaan distribusi yang diperoleh dapat diterima. Perhitungan uji kecocokan sebaran dengan SmirnovKolmogorov untuk agihan Log Pearson III dapat dilihat pada Tabel 6 .

Metode yang digunakan dalam perhitungan curah rencana ini adalah metode Log Perason III. Dari perhitungan parameter statistik diperoleh nilai $\mathrm{S}=0,10070$ dan nilai $\mathrm{Cs}$ $=0,81665$. Perhitungan curah hujan rencanan dengan 
berbagai kala ulang dihitung dengan menggunakan Persamaan 2. Selanjutnya data hujan PMP sebesar 442,51 yang diperoleh dari Balai Besar Wilayah Sungai Serayu Opak pada tahun 2016 digunakan untuk memperkirakan debit banjir rancangan guna menguji keruntuhan bendungan. Hasil perhitungan curah hujan rencana tersebut ditampilkan pada Tabel 7.

Rancangan hyetograph dibuat dengan metode Alternating Block Method (ABM). Durasi hujan di indonesia berkisar antara 4-7 jam dan dalam analisis ini diambil 5 jam. Hasil perhitungan hyetograph untuk berbagai kala ulang dapat dilihat pada Tabel 9.

Di daerah di mana data hidrologi tidak tersedia untuk menurunkan hidrograf satuan, maka dibuat hidrograf satuan sintetis yang didasarkan pada karakteristik fisik dari DAS. Dalam hal ini perhitungan dilakukan dengan menggunakan metode Hidrograf Satuan Sintetis (HSS) Nakayasu. Dari perhitungan debit banjir rancangan didapatkan debit puncak banjir untuk berbagai kala ulang seperti pada Tabel 8.

Tabel 3. Curah Hujan Maksimum $(\mathrm{CH})$

\begin{tabular}{ccc}
\hline No & Tahun & CH $(\mathrm{mm})$ \\
\hline 1 & 2010 & 73 \\
2 & 2010 & 136 \\
3 & 2010 & 73 \\
4 & 2010 & 103 \\
5 & 2010 & 79 \\
6 & 2011 & 71 \\
7 & 2011 & 93 \\
8 & 2011 & 81 \\
9 & 2011 & 101 \\
10 & 2012 & 131 \\
11 & 2012 & 68,143 \\
12 & 2012 & 85,032 \\
\hline
\end{tabular}

Tabel 4. Pemilihan Jenis Distribusi Menurut Kriteria [3]

\begin{tabular}{lllll}
\hline Distribusi & Persyaratan & & Hasil & Keterangan \\
\hline Normal & $\mathrm{Cs}=$ & 0,00 & 1,11 & Tidak Memenuhi \\
& $\mathrm{Ck}=$ & 3,00 & 3,93 & Tidak Memenuhi \\
Gumbel & $\mathrm{Cs}=$ & 1,14 & 1,11 & Tidak Memenuhi \\
& $\mathrm{Ck}=$ & 5,4 & 3,93 & Tidak Memenuhi \\
\multirow{2}{*}{ Log Normal } & $\mathrm{Cs}=\mathrm{Cv}^{3}+3 \mathrm{Cv}$ & 0,00332 & 0,81665 & Tidak Memenuhi \\
& $\mathrm{Ck}=\mathrm{Cv}^{8}+6 \mathrm{Cv}^{6}+15 \mathrm{Cv}^{4}+16 \mathrm{VC}^{2}+3$ & 3,00002 & 3,35729 & Tidak Memenuhi \\
Log Pearson III & Selain dari nilai diatas & & 0,81665 & Memenuhi \\
& & & 3,35729 & Memenuhi \\
\hline
\end{tabular}

Tabel 5. Hasil Pengujian Chi-Kuadrat

\begin{tabular}{cccccc}
\hline & & & & \multicolumn{2}{c}{${\text { (Ef-Of })^{2}}^{\text {Ef }}$} \\
\hline 1 & Interval Kelas & Of & Ef & Ef-Of & 1,067 \\
& $59,71<\mathrm{P} \leq 76,58$ & 2,4 & 4 & 2,56 & 1,067 \\
2 & $76,58<\mathrm{P} \leq 93,45$ & 2,4 & 4 & 2,56 & 0,067 \\
4 & $93,45<\mathrm{P} \leq 110,33$ & & & 0,16 & 2,400 \\
5 & $110,33<\mathrm{P} \leq 127,20$ & 2,4 & 2 & 5,76 & 0,067 \\
& $127,20<\mathrm{P} \leq 144,07$ & 2,4 & 0 & 0,16 & $\mathrm{X}^{2}$ \\
\hline
\end{tabular}

Tabel 6. Hasil Pengujian Smirnov-Kolmogorov 


\begin{tabular}{rccccrrc}
\hline No & $\mathrm{X}$ & $\mathrm{M}$ & $\mathrm{P}(\mathrm{x})=\mathrm{m} /(\mathrm{n}+1)$ & $\mathrm{P}(\mathrm{x})=1-\mathrm{p}$ & $\mathrm{P}^{\prime}(\mathrm{x})=\mathrm{m} /(\mathrm{n}-1)$ & $\mathrm{P}^{\prime}(\mathrm{x})=1-\mathrm{P}^{\prime}$ & $\mathrm{D}$ \\
\hline 1 & 73,045 & 1 & 0,07692 & 0,92308 & 0,09091 & 0,90909 & 0,01399 \\
2 & 135,638 & 2 & 0,15385 & 0,84615 & 0,18182 & 0,81818 & 0,02797 \\
3 & 73,241 & 3 & 0,23077 & 0,76923 & 0,27273 & 0,72727 & 0,04196 \\
4 & 102,567 & 4 & 0,30769 & 0,69231 & 0,36364 & 0,63636 & 0,05594 \\
5 & 78,631 & 5 & 0,38462 & 0,61538 & 0,45455 & 0,54545 & 0,06993 \\
6 & 70,698 & 6 & 0,46154 & 0,53846 & 0,54545 & 0,45455 & 0,08392 \\
7 & 92,929 & 7 & 0,53846 & 0,46154 & 0,63636 & 0,36364 & 0,09790 \\
8 & 81,246 & 8 & 0,61538 & 0,38462 & 0,72727 & 0,27273 & 0,11189 \\
9 & 100,730 & 9 & 0,69231 & 0,30769 & 0,81818 & 0,18182 & 0,12587 \\
10 & 131,034 & 10 & 0,76923 & 0,23077 & 0,90909 & 0,09091 & 0,13986 \\
11 & 68,143 & 11 & 0,84615 & 0,15385 & 1,00000 & 0,00000 & 0,15385 \\
12 & 85,032 & 12 & 0,92308 & 0,07692 & 1,09091 & 0,09091 & 0,16783 \\
& & & & & & & 0,16783 \\
\hline
\end{tabular}

Tabel 7. Data $K_{T}, \log T_{R}$, dan $X_{T R}$.

\begin{tabular}{lcccc}
\hline \multicolumn{1}{c}{$\mathrm{T}_{\mathrm{R}}$} & $\begin{array}{c}\text { Probabilitas } \\
(\%)\end{array}$ & $\mathrm{K}_{\mathrm{T}}$ & $\log \mathrm{T}_{\mathrm{R}}$ & Curah Hujan Rencana (X $\left.\mathrm{X}_{\mathrm{TR}}\right)$ \\
\hline 2 & 50 & $-0,13$ & 1,93 & 86 \\
5 & 80 & 0,77 & 2,02 & 106 \\
10 & 90 & 1,33 & 2,08 & 120 \\
25 & 96 & 1,99 & 2,14 & 141 \\
50 & 98 & 2,46 & 2,19 & 157 \\
100 & 99 & 2,90 & 2,24 & 173 \\
200 & 99,5 & 3,32 & 2,28 & 191 \\
\hline
\end{tabular}

Tabel 8. Puncak Banjir Berbagai Kala Ulang

\begin{tabular}{cc}
\hline $\begin{array}{c}\text { Kala Ulang } \\
\text { (Tahun) }\end{array}$ & $\begin{array}{c}\text { Debit Puncak } \\
\left(\mathrm{m}^{3} / \mathrm{dt}\right)\end{array}$ \\
\hline 2 & 99,39 \\
5 & 207,67 \\
10 & 299,93 \\
25 & 446,17 \\
50 & 587,65 \\
100 & 746,55 \\
200 & 918,20 \\
$P M F$ & 3320,59 \\
\hline
\end{tabular}


Tabel 9. Hyetograph Metode $A B M$ Berbagai Kala Ulang

\begin{tabular}{cccccc}
\hline \multirow{2}{*}{ Kala Ulang } & \multicolumn{5}{c}{ Waktu (Jam) } \\
& 1 & 2 & 3 & 4 & 5,1 \\
\hline 2 & 7,3 & 13,0 & 50,3 & 9,1 & 7,6 \\
5 & 9,0 & 16,1 & 62,1 & 11,3 & 8,6 \\
10 & 10,2 & 18,3 & 70,7 & 12,9 & 10,1 \\
25 & 11,9 & 21,4 & 82,4 & 15,0 & 11,2 \\
50 & 13,3 & 23,8 & 91,8 & 16,7 & 12,4 \\
100 & 14,7 & 26,4 & 101,7 & 18,5 & 13,7 \\
200 & 16,2 & 29,1 & 112,2 & 20,4 & 31,7 \\
$P M F$ & 37,5 & 67,2 & 258,7 & 47,1 & \\
\hline
\end{tabular}

\subsection{Simulasi Genangan Banjir}

Hasil Running HEC-RAS didapatkan nilai kedalaman banjir, kecepatan aliran dan elevasi muka air. Pada penelitian ini ditentukan tiga titik sebagai acuan untuk menganalisa banjir yaitu: Titik A sebagai hulu atau yang paling dekat dengan bendungan; Titik $\mathrm{B}$ sebagai titik tengan dari area terdampak yang berada di sekitar Bendung Pejengkolan; Titik $\mathrm{C}$ sebagai hilir area yang dianalisis. Peta titik lokasi dapat dilihat pada Gambar 3.

Setelah dilakukan berbagai macam percobaan dari berbagai kala ulang hujan mulai dari dua tahun hingga 200 tahun, diperoleh data bahwa bendungan masih mampu menampung debit banjir yang masuk ke waduk. Maka dari itu dilakukan analisis untuk kala ulang $P M F$ untuk mengetahui apakah bendungan masih mampu menampung debit banjir $P M F$. Saat dilakukan permodelan dengan menggunakan debit banjir PMF, waduk tidak mampu menampung debit banjir yang masuk sehingga air keluar melewati mercu bending dan mengakibatkan bendungan runtuh. Keruntuhan tersebut biasa disebut dengan overtopping. Saat bendungan runtuh maka air akan mengalir menuju ke daerah yang lebih rendah. Waduk wadaslintang berada di daerah perbukitan, maka dari itu saat bendungan ini runtuh air akan melimpas turun menuju ke arah Kota Prembun karena berada segaris lurus dengan bendungan dan juga berada pada daerah rendah. Areal yang terdampak cukup luas yaitu mencakup dua kabupaten yaitu Kabupaten Kebumen dan Kabupaten Purworejo. Peta sebaran genangan banjir dengan kala ulang $P M F$ dapat dilihat pada Gambar 4.

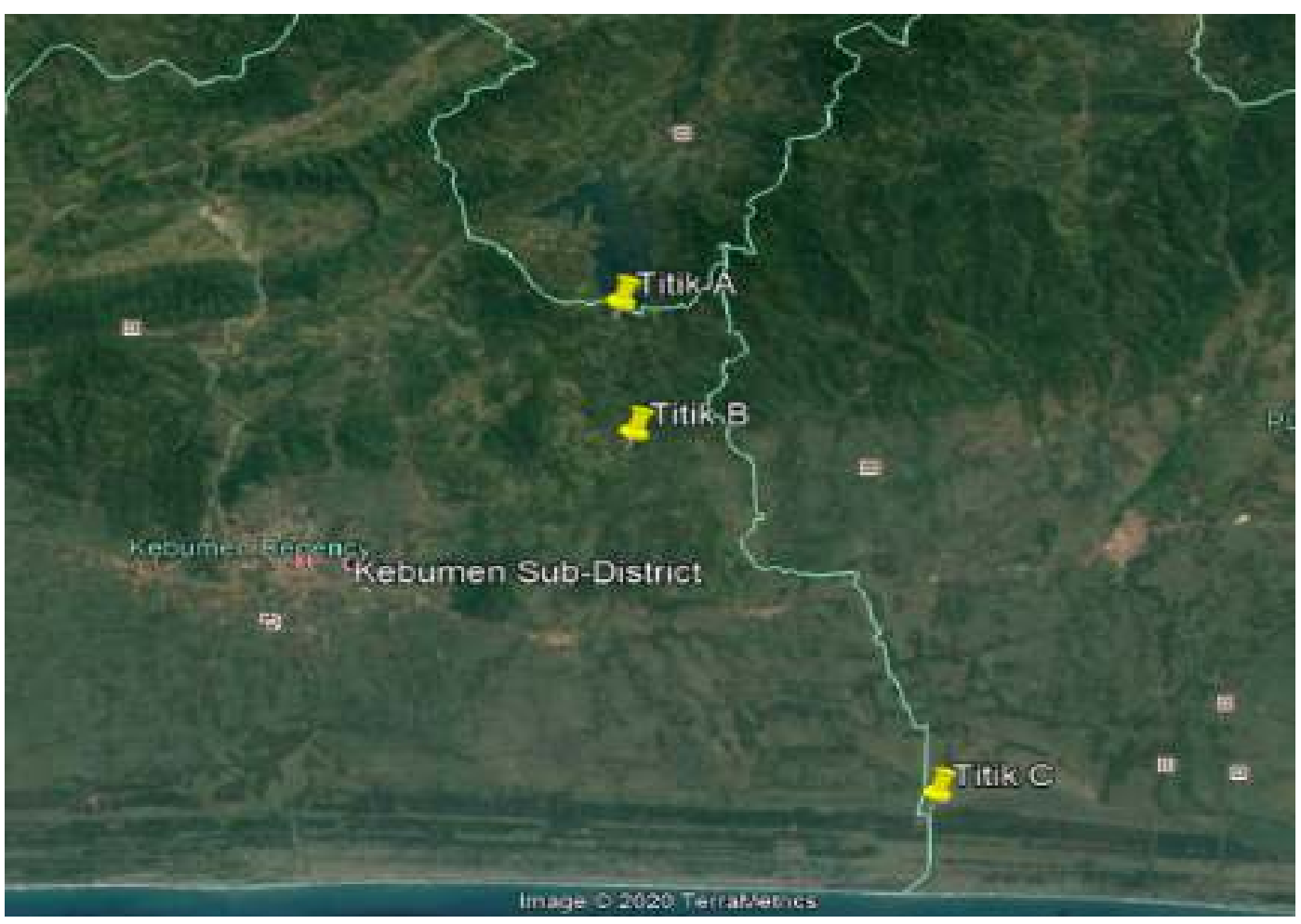

Gambar 3. Peta Titik Lokasi Analisis 


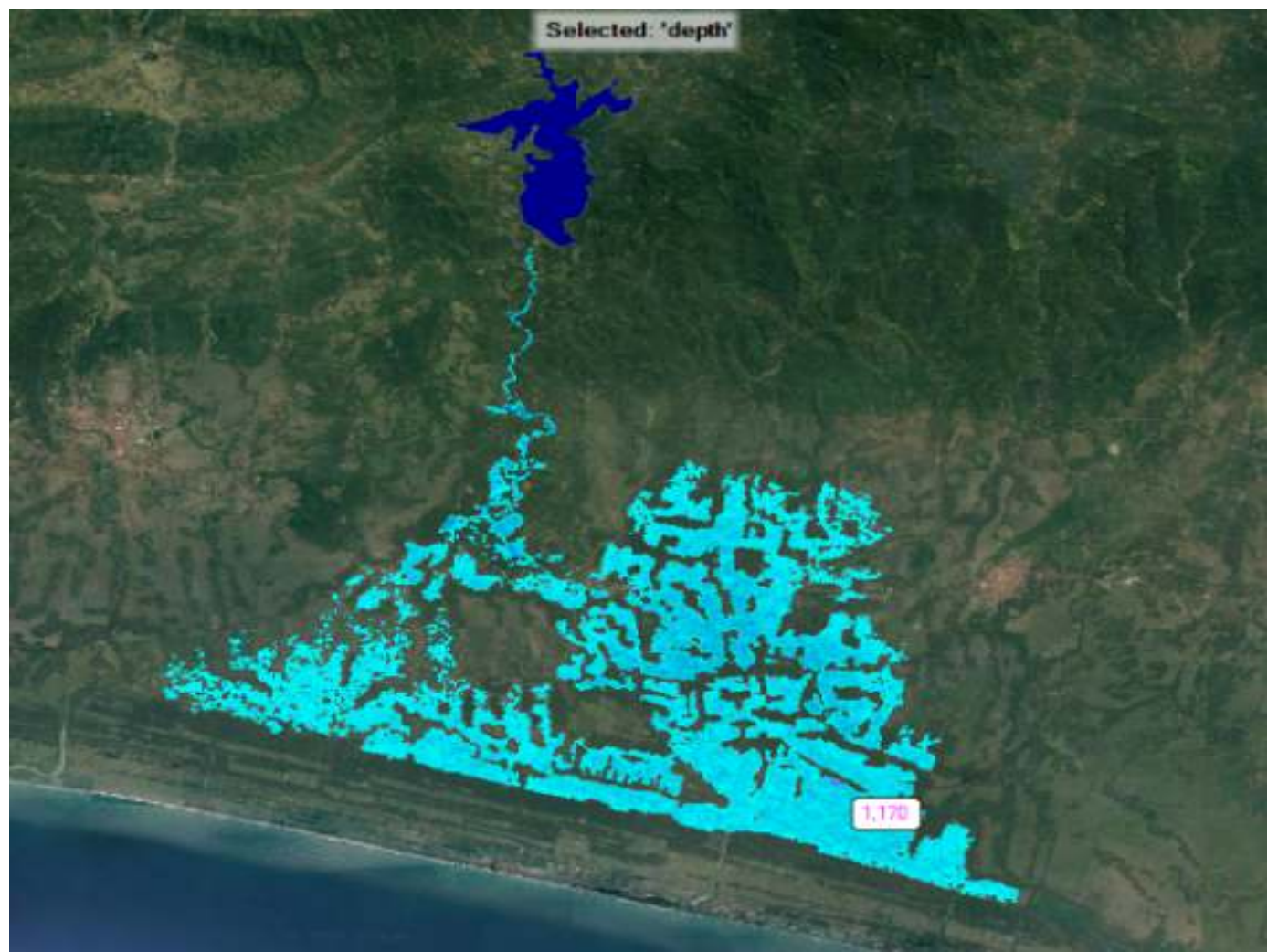

Gambar 4. Peta Lokasi Genangan

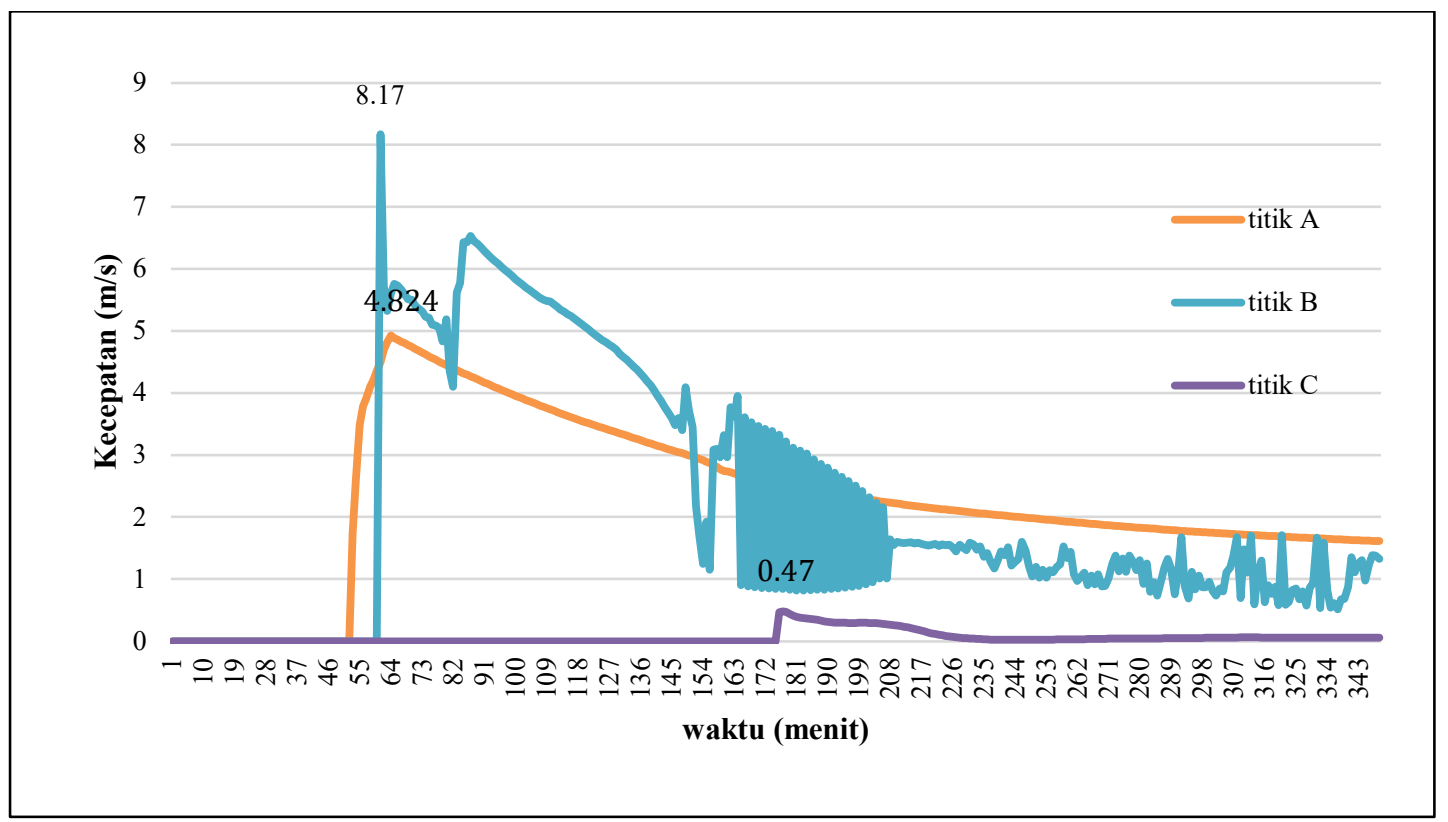

Gambar 5. Kecepatan Banjir

Dari ketiga titik yang telah dipilih untuk dilakukan dianalisis, didapatkan hasil kedalaman dan kecepatan banjir dapat dilihat pada Gambar 5.

Jika dicermati pada Gambar 5 grafik kecepatan banjir untuk kasus penjalaran dam break dengan QPMF kecepatan terbesar adalah sebesar $8,17 \mathrm{~m}^{3} / \mathrm{dt}$. Sebagai peringatan dini untuk bahaya banjir, waktu yang ditempuh hidrograf banjir dari Bendungan Wadaslintang sampai hilir adalah jarak antara tempat tersebut dibagi kecepatan puncak banjir. $(22750 / 8,17=2784,58 \mathrm{dt}=0,78 \mathrm{jam}$.

\section{Simpulan}

Berdasarkan hasil running program HEC-RAS beserta hasil analisis yang telah dilakukan pada penelitian ini adalah bendungan breaking pada QPMF, sedangkan untuk debit banjir kala ulang lainnya bendungan tidak breaking karena bendungan masih mampu menampung debit banjir 
yang masuk. Saat bendungan runtuh, semakin besar debit banjir yang masuk, maka kecepatan maksimum penjalaran hidrograf banjir akan semakin besar dan waktu tempuh dari Bendungan Wadaslintang sampai hilir semakin kecil. Dari studi ini dapat dipahami bahwa hilir DAS Wawar kira kira akan terlibas banjir dalam waktu 0,78 jam dengan area tergenang yang cukup luas yakni meliputi sebagian kawasan pada Kabupaten Kebumen dan Kabupaten Purworejo.

\section{Daftar Rujukan}

[1] Balai Besar Wilayah Sungai Serayu Opak, Balai Besar Wilayah Sungai Serayu Opak Rekomendasi teknik. Yogyakarta, 2016.

[2] Balai PSDA Bogowonto Luk Ulo, Balai PSDA
Bogowonto Luk Ulo Rekomendasi teknik. Purworejo, 2016.

[3] B. Triatmodjo, Hidrologi Terapan. Yogyakarta: Beta Offset, 2008.

[4] Suripin, Sistem Drainase Perkotaan Yang Berkelanjutan. Jakarta: Andi Offset, 2004.

[5] C. D. Soemarto, Hidrologi Teknik. Jakarta: Penerbit Erlangga, 1999.

[6] M. Gee, Guidelines for Dam Breach Analysis. Colorando: , Department, Natural Resources Division of Water Resource, 2006.

[7] G. . Brunner, HEC-RAS, River Analysis System Hydraulic Reference Manual. California: U,S, Army Corps of Engineers, Institute Ror Water Resources, Hydrologic Engineering Center, Davis, CA, USA, 2010. 